\title{
Apology Strategies in Cameroon Pidgin English
}

\author{
Jean-Paul Kouega \\ University of Yaounde I, Yaounde, Cameroon \\ Email: jkouega@yahoo.co.uk
}

How to cite this paper: Kouega, J.-P. (2018) Apology Strategies in Cameroon Pidgin English. Open Access Library Journal, 5: e4308.

https://doi.org/10.4236/oalib.1104308

Received: January 4, 2018

Accepted: January 28, 2018

Published: January 31, 2018

Copyright (๑) 2018 by author and Open Access Library Inc.

This work is licensed under the Creative Commons Attribution International License (CC BY 4.0).

http://creativecommons.org/licenses/by/4.0/

\begin{abstract}
This study looks into the apology strategies used by adult speakers of Cameroon Pidgin English, an area which has received little attention. The data consisted of some 105 recalled conversations between an offender and an offendee and the analysis drew from the model developed by Bergman and Kasper [1]. The analysis revealed a number of facts. First the common contexts which require that someone should apologise to his/her mate include, amongst others, lies or gossiping, insulting or embarrassing one's partner, cheating on or deceiving a partner, and stealing or taking away property without permission. Second, the most common strategies employed by these speakers were found to include: use of illocutionary force device (100\% of 105 conversations), recall of the offence (86.67\%), use of address terms $(66.67 \%)$, and lastly, use of devices to reduce the severity of the offence (60\%).
\end{abstract}

\section{Subject Areas}

Linguistics

\section{Keywords}

Cameroon Pidgin English, Orthography, Pragmatics, Speech Act, Apology, Offence, Repair

\section{Introduction}

Cameroon Pidgin English has been in use for over 500 years today as it started up with the Slave Trade in West African Coast. It evolved steadily over the years, and resisted a ban in 1884 when the Germans annexed Cameroon. Today, it has invaded all domains of public life. Despite its spread, it is despised by its most fluent speakers as it is associated with illiteracy, ruralness and poverty. While many aspects of this language have been tackled over the years-as the review below shows, the area of pragmatics in general and of apology in particular, has received very little attention. This study set out to describe apology in this lan- 
guage, with the focus on identifying the contexts in which apology is required and the common strategies fluent speakers use. Two questions are set to guide this research; these questions (RQ) are:

RQ1. What are the contexts which require that someone should apologise to his/her mate in Cameroon?

RQ2. What are the common apology strategies used by fluent adult speakers of Cameroon Pidgin English?

This research is highly significant as its finding can be used to enrich literacy materials, as some people-like American Peace Corps, agriculture extension workers, politicians, to name only these-need competence in it in order to do their jobs.

\section{Background to the Study}

Researchers who have developed interest in Cameroon Pidgin English have looked into it from four broad perspectives: sociolinguistics, grammar, phonology, and lexicology and lexicography, with the levels of pragmatics and discourse receiving very little attention. Significant sociolinguistic works include amongst others: Mbassi-Manga [2]; Féral [3] [4] [5]; Mbangwana [6]; Alobwede [7]; Kouega [8]; Mbufong [9]; Schröder [10]; Simo Bobda and Wolf [11], Ayafor [12], Echu [13], and Ngefac [14]. These works report that Cameroon Pidgin English is a major lingua franca in Cameroon and that it is used in all domains of social life including the neighbourhood, religion, and the media. However many Cameroonians, Francophone and Anglophone, literate and illiterate, young and old, male and female, have a negative attitude to it as they claim that it would interfere with children learning of English. Major works on grammar like Todd [15], Ngefac [16], Nkemngong Nkengasong [17], and Ozon, Ayafor, Green and Fitzgerald [18] have described the sentence structure of this language while those on phonology have described its sound system (Todd [15], Kouega [19]). The area of lexis was tackled by Kouega [19] [20]. Works on discourse include are few (Kouega [21] [22]). The work on pragmatics of a certain size recorded so far is Nkwain [23].

In all these works, the issue of developing an orthography for Cameroon Pidgin English is raised. Significant proposals were made by Todd [15], Ayafor [24] [25] and Kouega [19] [20]. Todd used a phonetic-based writing system while Ayafor and Kouega used the Roman alphabet system. Ayafor [24] [25] made use of accents to represent some vowels while Kouega [19] [20] used alphabet letters to represent these vowels and to compile a dictionary of this language. In 2014, Ayafor tried to use her proposed orthography to write out the Cameroon Pidgin spoken corpus she was building and she realised that her proposed spelling system needed to be revised substantially. As her research team (Ozon, Ayafor, Green, and Fitzgerald [18], p. 435) reported:

Given the absence of a standardised orthography, the research assistants were trained in the orthography system developed by Ayafor [25], but the 
spelling system necessarily had to be fully developed alongside the transcription, which required constant revision of the transcriptions as the spelling guide was developed.

What these researchers seem to have failed to notice is that as their spelling system was developing alongside the transcription, it was moving gradually toward the spelling system already established by Kouega [19] [20], which they did not review in their works. Presently the publications of this research team have adopted most of the features of the spelling system outlined in Kouega's works. There remain a few significant differences which the team will eventually have to look into. Compare for example the spelling of the words listed in Table 1. For example, as the Pidgin entries for the words "for", "go", "no" and "so" show, words ending in the letter -O- or -OR- are made to take the final letter -E-; so "for" is spelt "foe" and "go" is spelt "goe". There seems to be no justification for the use of this additional letter. The same goes for the other illustrations entered in Table 1.

Also, the team had to make some "small changes in the orthographic representation of certain words". These are: ol ting which became olting and som man which became somman. Thanks to this decision, they reported, one single tag was assigned to each pronoun. This decision solves one problem by creating many other problems. If som man is compounded into somman, how will the following words be written: som kana (some kind of), som pesin (some person i.e. someone), som taim (some time i.e. perhaps), som tin (some thing i.e. something). If ol ting is written olting as suggested, what will become of: ol man (all man i.e. everybody), ol ol (all-all i.e. completely, totally). These questions will have to be answered by this team and their answers are likely to lean towards not compounding these words, which is what Kouega [19] [20] did.

\section{Literature Review}

Works on the study of apology abound in the literature but are rare in Cameroon Pidgin English. A good number of existing works compare and contrast the strategies used by native English speakers and English language learners of various countries and cultures. A few examples include: Abu-Humei [26], Alsulayyi [27], Batanieh and Batanieh [28] and Cohen and Olshtain [29]. One interesting work that has established a model of analysis of native and non-native speech acts is produced by Bergman and Kasper [1]. They worked out a list of six apology strategies that are dominant in native and non-native speakers' interactions. These are:

1) Illocutionary Force Indicating Device

This strategy expresses regret explicitly; it always contains apologetic expressions like "sorry", "excuse me", "forgive me", "I regret", as Blum-Kulka \& Olshtain [30] point out. These expressions clearly tell the offended person that the offender regrets what he/she has done and that what he/she wants is forgiveness. 
Table 1. Major differences between the proposed spelling systems for Cameroon Pidgin English.

\begin{tabular}{|c|c|c|}
\hline Words & Kouega [19] [20] & Ozon, Ayafor, Green, and Fitzgerald [18] \\
\hline bear risk & (not attested) & bear risk \\
\hline bridge & brich & breich \\
\hline day & de & dei \\
\hline $\operatorname{dig}$ & dik & $\operatorname{dig}$ \\
\hline ever, never & no bi & noebi \\
\hline for & fo & foe \\
\hline go & go & goe \\
\hline have not ever seen & no bi (don eva si) & noebi (don eva si) \\
\hline he & yi & $\mathrm{i}$ \\
\hline hold & hol & hole \\
\hline is (to be) & de & deiy \\
\hline it & yi & $\mathrm{i}$ \\
\hline keep it & kip-am & kipam \\
\hline know & no & nou \\
\hline mouth & mop, maut & mob \\
\hline never & noba, neba, neva & nova \\
\hline new & niu & nyu \\
\hline not & no & noe \\
\hline pay & pe & pei \\
\hline plank & plan, plank & plang \\
\hline so & so & soe \\
\hline swear & swe & swel \\
\hline that & se, sei & sei \\
\hline they & de & dey \\
\hline thing & tin & ting \\
\hline village & vilech, vilej & vileich \\
\hline what & we & wei \\
\hline you (plural) & wona, wuna & wuna \\
\hline
\end{tabular}

2) Upgrader and apology strategies

These are intensifying adverbs which give more power to the apologetic expressions used, like "very", "so", "terribly", etc.

3) Taking on responsibility

The offender takes up various actions, verbal and non-verbal, to make up for his offence. This strategy, Cohen and Olshtain [31] had observed, can be divided into three sub-types called: expression of self-blame, expression of lack of intent and expression of admission of fact. 
4) Downgrading responsibility or the severity of the offence

Here the speaker tries to reduce his/her responsibility for the offence. He/she may claim ignorance, provide justifications, put forward a precondition, and even deny the offence altogether.

5) Offers of repair

The offender may wish to repair the damage brought about by his/her offence, like fixing a broken indicator of a car or offering payment in certain cases.

6) Verbal redress

The offender uses relevant expressions showing concern for the offended person.

The model thus outlined was used by a number of researchers. Alsulayyi [27], in a recent study, examined the apology strategies employed by Saudi EFL teachers. Using a discourse completion test, he gathered relevant data in ten specific situations. The analysis of these data revealed that Illocutionary Force Indicating Device was the most frequently used apology strategy among these teachers, followed by downgrading responsibility. In another study, this same researcher (Alsulayyi [32]) adopted this model to compare the use of apology strategies employed by Saudi EFL teachers and British native speakers of English. To guide this study, he set the following research questions:

a) What are the apology strategies used by British native speakers of English in expressing regret?

b) Does the respondents' gender affect their use of apology strategies?

c) How do Saudi EFL teachers differ from British native English speakers in using apology strategies?

d) How do apology strategies differ between Saudi EFL teachers and British native speakers of English in terms of gender?

His informant pool consisted of 30 British native speakers of English and 30 Saudi EFL learners and the tool he used was the same Discourse Completion Test as in his 2016 study. The ten situations outlined in this test included a borrowed car that got damaged, a borrowed magazine that got torn, a student that was failed by mistake, a borrowed book that was not returned on time, to name only these. The analysis revealed among other things that downgrading strategies were the most frequent strategies used by British native speakers of English. This was followed by Illocutionary Force Indicating Device, taking on responsibility, upgrader, offer of repair and lastly verbal redress. On the contrary, Illocutionary Force Indicating Device turned out to be the dominant strategy among Saudi teachers, followed in turn by downgrading responsibility, upgrader, offer of repair, taking on responsibility and finally, verbal redress.

As far as Cameroon Pidgin English is concerned, works on apology in this language are rare. One seminal work on speech acts was conducted by Nkwain [23], an unpublished $\mathrm{PhD}$ thesis which examined the polite linguistic behaviour of speakers of Cameroon Pidgin English, drawing from Brown and Levinson [33]. His data came from a 45 -item questionnaire in which his informants were 
to indicate what expressions they would use to address people of various statuses, make an offer, compliment someone, agree with someone, to name only these. From their answers he found that these informants made use 42 politeness strategies i.e. 15 positive strategies, 10 negative strategies, 7 bald-on-record strategies and 10 off-record strategies. First, positive strategies which include address terms and titles, providing justifications, complimenting, flattery and the like, are said to "minimize threats to the hearer's positive face and make him/her feel good about his/her possessions, interests, and aspirations". Second, negative strategies "address the hearer's negative face by avoiding imposition"; these include: apologizing, making promises, evoking compassion, polite interrogations, polite verifiers etc. Third, off-record strategies are used to "minimize threat to the hearer's face wants through the use of speech acts with dual meaning"; they include various tactics some of which are: giving advice, ironical utterances, euphemistic usage, teasing insults, implicit negative assertions and silence. Lastly, bald-on record strategies "are explicit speech acts which do not minimize threats to the hearer's face wants and foster solidarity ties." They are said to include: refusing requests and offers, managing mishearing and misunderstanding, greeting and farewell, attention-getting exclamations and gratifying, and the use of diminutive quantifiers.

Apologizing in this work falls under "negative politeness strategies", and is said to include three types labelled: "apologising mitigators", "excusing", and "expressing regret and swearing". The first type, "apologizing mitigators", which represented $55.07 \%$ of the 2504 cases in the data he collected, was said to be used to accompany excuses following wrongdoing; it is realized by the following words and expressions: ashia (sorry), A bek (I beg), plis (please), we'eh! (an exclamation expressing regret). The second type called "Excusing" was said to be used by the speaker to express what he feels; this type which represented $35.62 \%$ of the 2504 cases in the data, was realised by expressions like: no vex (don't be angry), no wori (do not worry yourself), chus me (forgive me), A no go du-am egen (I will never do it again). Lastly, the third type called "expressing regret and swearing", which represented $9.31 \%$ of 2504 cases, was said to be explicit remorse following wrongdoing; it was found to be realized by expressions like: onli if $A$ fo no... (had it been I knew...), Na weti ivin du mi-eh (What even came over me?), $A$ swe to God se (I swear in God's name that...).

The present study focuses on apology, drawing from Bergman and Kasper [1]'s model of analysis, which has been applied successfully by Alsulayyi [27] [32], amongst other researchers.

\section{Methodology}

The informants for the study, the tools used, the preparation of research assistants, and the data analysis procedure are outlined below. The informants were self-reported fluent adult speakers of Cameroon Pidgin English, aged from 20 to above 75 years. They were contacted in four localities in Cameroon: Yaounde 
where a pilot study was conducted, and Buea, Limbe and Kumba, three cosmopolitan towns located in the Southwest Region of Cameroon, this region being the seat of Pidgin in Cameroon.

The tools used were a seven-item questionnaire that was used to identify appropriate informants, and the materials collected were recalled conversations. Informants who were literate in English were asked by research assistants to write out an actual conversation in which they were the offender or the victim; illiterate informants were asked to dictate their conversations in Pidgin for the research assistants to write them out for them. These research assistants were a group of motivated students majoring in Sociolinguistics in the University of Yaounde I. They were contacted by the researcher who explained to them what they were to do: identify appropriate informants in each setting, ask them a number of questions, and get them to write out a recalled conversation or to dictate a recalled conversation for these researcher assistants to help them to write it out. The 15 assistants who were retained for the task had successfully gathered two recalled conversations in Yaounde, one from a literate informant and one from an illiterate informant. They were then sent to the localities cited above, which were their hometowns, with the mission to bring back five conversations each, two from literate informants and three from illiterate informants. The 105 conversations thus collected were analysed using the simple frequency and percentage method.

\section{Analysis}

The section is divided into two sub-sections labelled analysis of the questionnaire, and linguistic analysis of conversation samples.

\subsection{Analysis of the Questionnaire}

The first of the seven questions (Q1) asked the informants whether they spoke Pidgin English well. This question helped the research assistants to identify relevant informants for the study. People who claimed to be competent in Pidgin were then asked if they could speak and write English (Q2) and their answers helped to group the conversations into two categories: those made by literate informants and those made by illiterate informants. The literacy variable can help to check whether knowledge of English has an effect on the form or structure of apology in Pidgin English. Q3 asked the respondents to indicate what indigenous language and culture they hailed from, as some apology features may be drawn from these backgrounds. It turned out that the 105 informants spoke a total of 50 indigenous languages (see list of Cameroonian languages in Kouega, [34], and Lewis et al., [35]). Q4 asked these informants to name any three things that someone can do to them that require that he/she should apologise. The situations in Table 2, which are loosely grouped into some 11 categories, were cited by the 105 informants.

Table 2 reveals that lies and similar offences are the most frequent situations 
Table 2. Situations requiring an apology cited by the informants.

\begin{tabular}{|c|c|c|c|}
\hline & Situations & Number & Percentage \\
\hline 1 & $\begin{array}{l}\text { Lies, spreading false rumours, gossiping, betraying, spreading secrets, bearing false witness, conspiracy, } \\
\text { accusation (false), blackmail }\end{array}$ & 100 & 31.75 \\
\hline 2 & $\begin{array}{l}\text { Insulting in public, belittling, looking down on a partner, shouting, embarrassing, snubbing, mocking at } \\
\text { someone, disrespecting, despising, disgracing, being rude, ignoring a partner in public }\end{array}$ & 80 & 25.4 \\
\hline 3 & Cheating in a relationship, heartbreak, disappointment, failure to honour an invitation, deceiving, & 60 & 19.05 \\
\hline 4 & Theft, stealing, take things away without permission, being selfish & 50 & 15.87 \\
\hline 5 & Maltreating, beating for no reason, slapping, causing pain, hurting & 10 & 3.17 \\
\hline 6 & Disobedience, headiness, insolence & 4 & 1.27 \\
\hline 7 & Borrowing and failing to pay back, destroying property & 3 & 0.95 \\
\hline 8 & Abandoning a friend in need (like a sick person in a hospital) & 2 & 0.63 \\
\hline 9 & Promise (unfulfilled) & 2 & 0.63 \\
\hline 10 & Stepping on someone's toe, smashing, pouring dirty water on someone, splashing mud on someone & 2 & 0.63 \\
\hline \multirow[t]{2}{*}{11} & Failing to pass on useful information, negligence, misplacing documents & 2 & 0.63 \\
\hline & & 315 & 100 \\
\hline
\end{tabular}

requiring an apology; this is followed closely by insulting and similar wrongdoings. Actually, lies, insulting, cheating in a relationship and stealing together constitute $92.07 \%$ of the 315 offences in the corpus. This finding answers the first research question (RQ1): some 11 contexts which require that someone should apologise to his/her mate have been identified in the corpus.

Q5 asked the informants to recall a situation when a friend came to them to apologise or a situation in which they apologised to a friend for something they had done. Each of the informants easily recalled such a situation. Then they were asked to write out the conversation they had with their friend (Q6a) or to dictate the conversation for the researcher assistants to write it out. A total of 105 conversations were thus collected. A look at these conversations shows that they are of various lengths, ranging from three speaking turns to 20 speaking turns. Below is reproduced a seven-speaking turn conversation:

1) A. Wich kain man yu bi? Hau yu go manej brin anoda wuman rait fo wa rum, eer?

(What kind of man are you? How dare you bring another woman right into our room?)

2) B. We'eh, mom, A bi veri sori; de gel sidius mi. A bek, fogif mi.

(Oh, my love, I am very sorry, the girl seduced me. Please forgive me!)

3) A. An yu tin se yi bi izi fo jos fogif yu so?

(And you think that it is easy to just forgive you?)

4) B. Ma bebi, ma mami, ma wan an onli, A beg, fogif mi. (Kneeling on the ground with tears in his eyes) (My baby, my sweetheart, my "one and only one", please, forgive me.)

5) A. A don hie.

(I have heard.) 
6) B. A bek, mom, A promis se A no go eva du-am egen, yu hie? A bek.

(I beg, my sweetheart, I promise not to ever do that again. Have you heard, please?

7) A. Oke, as yu don promis mi so, A don fogif yu. Stan op. (They kiss each other.)

(OK, as you have made that promise to me, I forgive you. Stand up!)

\subsection{Linguistic Analysis of Conversation Samples}

First the frame outlined above is used to analyse the data collected, beginning with the conversation reproduced above. This conversation comprises four of the six strategies outlined in the frame. These are "Illocutionary Force Indicating Device", "Upgrader and apology strategies", "Downgrading responsibility or the severity of the offence" and finally "Taking on responsibility". These are illustrated in turn below.

Illocutionary Force Indicating Device

B. We'eh, mom, A bi veri sori; de gel sidius mi. A bek, fogif mi.

(Oh, my love, I am very sorry, the girl seduced me. Please forgive me!)

Upgrader and apology strategies

The offender here uses the expressions "very sorry"

B. We'eh, mom, A bi veri sori; de gel sidius mi. A bek, fogif mi.

(Oh, my love, I am very sorry, the girl seduced me. Please forgive me!)

Downgrading responsibility or the severity of the offence

B says: de gel sidius mi (the girl seduced me). Here B is trying to reduce his responsibility, by claiming that the girl seduced him.

Taking on responsibility

Here the offender takes up various actions including using address terms, begging, and asking for forgiveness; most importantly, he adds non-verbal features to his actions i.e. kneeling down and shedding tears.

B. Ma bebi, ma mami, ma wan an onli, A bek, fogif mi. (Kneeling on the ground with tears in his eyes.) (My baby, my sweetheart, my "one and only one", please, forgive me.)

In this conversation, the strategies "offers of repair" and "verbal redress" do not feature. Actually, there are many features in the conversation that still need to be analysed. There is therefore a need to enrich this frame outlined above by confronting it with various languages and cultures.

To find out what an apology conversation in Pidgin contains, there is a need to take up each speaking turn and check its function. Let us go over the very conversation reproduced above and work out the function of each of its seven speaking turns.

1) A. Wich kain man yu bi? Hau yu go manej brin anoda wuman rait fo wa rum, eer?

(What kind of man are you? How dare you bring another woman right into 
our room?)

This utterance can be referred to as "recall of the offence". The offended party is telling the offender what he has done.

2) B. We'eh, mom, A bi veri sori; de gel sidius mi. A bek, fogif mi.

(Oh, my love, I am very sorry, the girl seduced me. Please forgive me!)

The offender uses an exclamation (we'eh), an address term (mom-mummy) and an illocutionary force indicating device ( $A$ bi veri sori-I am very sorry), a device to reduce the severity of the offence (de gel sidius mi-the girl seduced me), another illocutionary force indicating device (plis-please) and finally a third an illocutionary force indicating device (fogif mi-forgive me).

3) A. An yu tin se yi bi izi fo jos fogif yu so?

(And you think that it is easy to just forgive you?)

The offended party refuses to accept the apology. Let us call this category "refusal".

4) B. Ma bebi, ma mami, ma wan an onli, A bek, fogif mi. (Kneeling on the ground with tears in his eyes.) (My baby, my sweetheart, my "one and only one", please, forgive me.) The offender pleads by piling up address terms (Ma bebi, ma mami, ma wan an onli) and illocutionary force indicating devices ("A bek", "fogif mi”). In addition, elements of non-verbal communication are brought in to show the sincerity of the pleading: kneeling down, shedding tears, surely with both hands lifted. It should be noted in passing that while shedding tears is drawn from apology situations in Cameroonian cultures, kneeling down obviously came from colonisation and the Christian religion.

5) A. A don hie.

(I have heard.)

Finally, the offended party accepts the apology. Let us call this category "acceptance"

6) B. A bek, mom, A promis se A no go eva du-am egen, yu hie? A bek.

(I beg, my sweetheart, I promise not to ever do that again. Have you heard, please?)

Then to double sure that acceptance is granted, the offender uses an illocutionary force indicating device (A bek), an address term (mom) and a promise of non-recurrence of this very offence (A promis se A no go eva du-am egen). Then he tries to comfort the offended party (yu hie?) and finally he uses an illocutionary force indicating device (A bek).

7) A. Oke, as yu don promis mi so, A don fogif yu. Stan op. (They kiss each other.)

(OK, as you have made that promise to me, I forgive you. Stand up!)

Finally the offended party takes note of the promise (Oke, as yu don promis $\mathrm{mi}$ so) and agrees to forgive the offender (A don fogif yu). She then orders him to stand up (Stan op) and another non-verbal action terminates the apology interaction (They kiss each other). There are three actions here i.e. acceptance of the promise, acceptance of the apology, and kissing.

In short, this text contains a total of ten categories that are combined in vari- 
ous ways to yield a successful apology. These ten categories are listed below, together with a few illustrations:

1) Recall of the offence

A. Wich kain man yu bi? Hau yu go manej brin anoda wuman rait fo wa rum, eer?

(What kind of man are you? How dare you bring another woman right into our room?)

2) Use of exclamation

We'eh

3) Use of address terms

Mom; ma bebi; ma mami; ma wan an onli.

4) Use of illocutionary force indicating devices

A bi veri sori; plis; fogif me; A bek.

5) Use of devices to reduce the severity of the offence

De gel sidius mi.

6) Refusal to accept the apology

An yu tin se yi bi izi fo jos fogif yu so?

(And you think that it is easy to just forgive you?)

7) Non-verbal communication

Kneeling down; shedding tears; kissing; movements of the hand (beckoning, raising the hands).

8) Acceptance of the apology

A don hie; oke; A don fogif yu.

9) Promise of non-recurrence of the offence

A promis se A no go eva du so egen.

10) Use of a comforting device

Yu hie?

Another apology text containing five speaking turns is reproduced below.

1) A. Weti yu di kam fain fo ma hos afta we yu akius mi se A di slip witi ya masa? Yu stil get da korej fo kam fo ma do afta yu don kosh mi sote-eeh-eeh.

(What are you coming to do in my house after accusing me of having an affair with your husband? You still have the gut to enter my house after insulting me profusely?)

2) B. We'eh! Ma kombi, no veks, yu hie, na som ma fren tel mi se yu an ma masa di folo. Na wai da A veks kom di kworel yu. A bek, no veks oh! Fogif mi.

(We'eh! My friend, don't be angry. Listen to me. It is a friend of mine who told me that you were going out with my husband. That is why I got angry and quarrelled with you. Please don't be angry! Forgive me.)

3) A. Eeeh! Maa no hie? Yu se weti? Maa fogif yu jos laik dat? Yu no wel? So, fo yu, A go jos fogif yu so. Yu get fo bek mi witi plenti kago.

(Eeeh! I do not want to hear that. What are you saying? That I should forgive you just like that? Are you alright? So, according to you, I should simply forgive you. You have to beg by giving me many presents.) 
4) Eeee woooh! Boh! Plenti kago laik weti noh?

(Eeee woooh! Boh! Many presents like what?)

5) Yu get fo go bai mi niu fon as yu bi veks trowe di oda wan, den yu bai mi kol jus an chiken bifo ol tin go pas. If yu no want-am, yu liv-am noh. No frenship.

(You have to buy a new phone for me, as you got angry and threw away the other one, then you will buy a cold fruit juice and a chicken before I accept your apology. If you do not want to buy these things, you leave me alone. No more friendship.)

There now follows an analysis of each of the five speaking turns making up this conversation:

1) A. Weti yu di kam fain fo ma hos afta we yu akius mi se A di slip witi ya masa? Yu stil get da korej fo kam fo ma do afta yu don kosh mi sote-eeh-eeh.

(What are you coming to do in my house after accusing me of having an affair with your husband? You still have the gut to enter my house after insulting me profusely?)

(Recall of the offence: the offended party recalls the offence, which is an accusation coupled with insult)

2) B. We'eh ! Ma kombi, no veks, yu hie, na som ma fren tel mi se yu an ma masa di folo. Na wai da A veks kom di kworel yu. A bek, no veks oh! Fogif mi.

(We'eh! My friend, don't be angry. Listen to me. It is a friend of mine who told me that you were going out with my husband. That is why I got angry and quarrel with you. Please don't be angry! Forgive me.)

This utterance contains: one exclamation (we'eh!), one address term (ma kombi), a comforting device (no vex), another comforting device (yu hie), a device to reduce the severity of the offence (na som ma fren tel $\mathrm{mi}$ se yu an ma masa di folo. Na wai da A veks kom di kworel yu.), an illocutionary force indicating device (A bek), a third comforting device (no veks oh), and finally an illocutionary force indicating device (fogif $\mathrm{mi}$ ).

3) A. Eeeh! Maa no hie. Yu se weti? Maa fogif yu jos laik dat? Yu no wel? So, fo yu, A go jos fogif yu so. Yu get fo bek mi witi plenti kago.

(Eeeh! I do not want to hear that. What are you saying? That I should forgive you just like that? Are you alright? So, according to you, I should simply forgive you. You have to beg me by giving me many presents.)

This utterance indicates refusal: the offended party refuses to accept the apology (Eeeh! Maa no hie. Yu se weti? Maa fogif yu jos laik dat? Yu no wel? So, fo yu, A go jos fogif yu so). Worse, she gives a pre-condition that needs to be fulfilled beforehand (Yu get fo bek mi witi plenti kago).

4) Eeee woooh! Bo, plenti kago laik weti noh?

(Eeee woooh! My friend! Many presents like what?)

This utterance in an inquiry: the offender checks what the pre-condition is (Eeee woooh! Boh! Plenti kago laik weti noh?) This is preceded by an interjection (Eeee woooh!) and an address term (bo). This particular interjection is as- 
sociated with some language groups in Cameroon but it may also be borrowed by speakers of other languages.

5) Yu get fo go bai mi niu fon as yu bi veks trowe di oda wan, den yu bai mi kol jus an chiken bifo ol tin go pas. If yu no want-am, yu liv-am noh. No frenship.

(You have to buy a new phone for me, as you got angry and threw away the other one, then you will buy a cold fruit juice and a chicken before I accept your apology. If you do not want to buy these things, you leave me alone. No more friendship.)

This utterance outlines the pre-condition: the offender must buy a new phone as she broke the offended person's phone, some juice and a chicken (Yu get fo go bai mi niu fon as yu bi veks trowe di oda wan, den yu bai mi kol jus an chiken bifo ol tin go pas.) This is followed by a very serious warning: the offender should feel free to buy these items or not. She should know that if she does not buy these items, then there would be no more friendship (If yu no want-am, yu liv-am noh. No frenship.)

In short, this text contains a total of nine categories that are combined in various ways. These nine categories are listed below, together with a few illustrations:

1) Recall of the offence

Weti yu di kam fain fo ma hos afta we yu akius mi se A di slip witi ya masa? Yu stil get da koraj fo kam fo ma do afta yu don kosh mi sote-eeh-eeh.

2) Use of interjections

We'eh!; Eeeh!; Eeee woooh!

3) Use of address terms

ma kombi; bo

4) Use of comforting devices

no vex, yu hie, no veks oh;

5) Use of a device to reduce the severity of the offence

Na som ma fren tel mi se yu an ma masa di folo. Na wai da $A$ veks kom di kworel yu.

6) Use of illocutionary force indicating devices

A bek, fogif mi

7) Refusal to accept the apology

Maa no hie. Yu se weti? Maa fogif yu jos laik dat? Yu no wel? So, fo yu, A go jos fogif yu so.

8) Use of pre-conditions

Yu get fo bek mi witi plenti kago, Plenti kago laik weti noh? Yu get fo go bai mi niu fon as yu bi veks trowe di oda wan, den yu bai mi kol jus an chiken bifo ol tin go pas.

9) Use of warnings

If yu no want-am, yu liv-am noh; no frenship

This conversation contains 9 categories of which six are found in the previous 
conversation. Three new ones have been identified i.e. the use of comforting devices, of preconditions and of warnings.

Other categories are identified in the corpus of 105 texts. These are: claiming ignorance, denial of the offence, giving evidence, repair of offence, and swearing.

Claiming ignorance

Hmmm! Ma fren. Yu di veks witi mi fo sika wet? (Hmmm! My friend, why are you angry with me?)

Denial of offence

Na lai. A nova kol ya nem fo som pesin. (It is a lie. I have not mentioned your name to anybody.); No bi tru (It is not true) No bi mi brok ya fon (It is not me who broke your phone $\approx$ I did not break your phone.)

Giving evidence

A bi di si yu taim we A bi di kol yu (I was seeing you as I was calling you.)

Repair of offence

Oke. A don chop chop ol. A go kuk anoda chop. (OK. I have offended you as I ate all the food. I will cook another food.); wi go fiks-am (We will fix it).

Swearing

A bek yu fo Got yi nem (I beg you in God's name)

In conclusion, the 105 texts collected for this study can be analysed in terms of the following 16 categories, which do not all occur in the same conversation, as the analysis of Texts 1 and 2 above has shown. These categories are listed in Table 3 .

Table 3 reveals that the common apology strategies identified in the corpus are: the use of illocutionary force indicating device (100\% of 105 conversations), recalling the offence $(86.67 \%)$, use of address terms (66.67\%), use of devices to reduce the severity of the offence (60\%), and accepting the apology (60\%). This finding answers the second research question (RQ2) i.e. the common apology strategies used by fluent speakers of Cameroon Pidgin English.

From this finding, it can be hypothesised the canonical structure of an apology in Cameroon Pidgin English comprises four elements sequenced as follows: Recall of the offence + use of address terms + use of illocutionary force indicating device + accepting the apology. A typical apology conversation involving people who are mates must therefore include the following three obligatory speaking turns, where $\mathrm{A}$ is the offended party and B, the offender:

A. Recall of the offence

B. Use of address terms + use of illocutionary force indicating device

A. Acceptance of the apology

\section{Conclusion}

This paper has examined a total of 105 recalled apology conversations produced by fluent speakers of Cameroon Pidgin English drawn from four localities in Cameroon i.e. Buea, Kumba, Limbe, and Yaounde. The analysis revealed that 
Table 3. Apology strategies used in the corpus.

Apology strategies

1. Recalling the offence

2. Claiming ignorance

3 Denial of the offence

$4 \quad$ Giving evidence

5 Use of interjections

6 Use of address terms

$7 \quad$ Use of comforting devices

8 Use of illocutionary force indicating devices

9 Use of devices to reduce the severity of the offence

10. Refusal to accept the apology

11. Non-verbal communication

12. Use of pre-conditions

13 Issuing warnings

14 Accepting of the apology

15 Promise of non-recurrence of the offence

16 Repair of the offence
Illustrative utterances

Proportion in 105 conversations

Wich kain man yu bi? Hau yu go manej brin anoda wuman rait fo wa rum, eer? (What kind of man are you? How dare you bring another woman into our room?)

Weti yu di kam fain fo ma hos afta we yu akius mi se A di slip witi ya masa? Yu

$(86.67 \%)$ stil get da koraj fo kam fo ma do afta yu don kosh mi sote-eeh-eeh.

Hmmm! Ma fren. Yu di veks witi mi fo sika weti? (Hmmm! My friend, why are you angry with me?)

$(14.29 \%)$

Na lai. A nova kol ya nem fo som pesin. (It is a lie. I have not mentioned your name to anybody.);

No bi tru (It is not true)

No bi mi brok ya fon (It is not me who broke your phone $\approx$ I did not break your phone.)

A bi di si yu taim we A bi di kol yu (I was seeing you as I was calling you.)

We'eh!; Eeeh!; Eeee woooh!

Mom; ma bebi; ma mami; ma wan an onli; ma kombi; bo.

no vex; yu hie; no veks oh;

A bi veri sori; plis; fogif mi; A bek; A bek yu fo Got yi name (I beg you in God's name).

105

$(100 \%)$

De gel sidius mi; na som ma fren tel mi se yu an ma masa di folo. Na wai da A veks kom di kworel yu.

$(60 \%)$

An yu tin se yi bi izi fo jos fogif yu so?

(And you think that it is easy to just forgive you?)

Maa no hie. Yu se weti? Maa fogif yu jos laik dat? Yu no wel? So, fo yu, A go jos fogif yu so)

Kneeling down; shedding tears; kissing; movements of the hand (beckoning, raising the hands)

Yu get fo bek mi witi plenti kago, Plenti kago laik weti noh? Yu get fo go bai mi niu fon as yu bi veks trowe di oda wan, den yu bai mi kol jus an chiken bifo ol tin go pas

there are some 11 situations that require that the offender should apologise to the offended party; these situations include: lies and similar misdemeanours, insulting and similar wrongdoings, cheating on one's partner in a relationship and 
similar offences, and stealing and similar felonies. It was also found that four apology strategies are dominant; these are: recall of the offence, the use of address terms, the use of illocutionary force indicating device, and accepting the apology. Some interesting issues came up but they could not be examined as the corpus was too small to give compelling evidence. These issues are: the linguistic features of signal wrongdoing and possible redress, the effect of competence in Standard English on apology in Cameroon Pidgin English, and gender differences in apology texts. It was found for example that all the preconditions in the corpus were made by women but there were only $6.67 \%$ cases out of 105 texts, a proportion which is too small for any valid conclusion to be drawn.

\section{References}

[1] Bergman, M. and Kasper, G. (1993) Perception and Performance in Native and Non-Native Apology. In: Gabrielle, K. and Shohona, B., Eds., Interlanguage Pragmatics, Oxford University Press, Oxford, 82-117.

[2] Mbassi-Manga, F. (1973) English in Cameroon: A Study of Historical Contacts: Patterns of Usage and Current Trends. PhD Thesis, Leeds University, Leeds.

[3] Féral, C. (1978) Le Pidgin English au Cameroun. Conseil International de la Langue Française. SELAF, Paris.

[4] Féral, C. (1980) Le Pidgin English Camerounais: Essai de Définition Linguistique et Sociolinguistique. Doctorat de 3e Cycle Thesis, Université de Nice.

[5] Feral, C. (1989) Pidgin-English du Cameroun: Description Linguistique et Sociolinguistique. Peeters/SELAF, Paris.

[6] Mbangwana, P.N. (1983) The Scope and Role of Pidgin English in Cameroon. In: Koenig, E.L., Chia, E. and Povey, J., Eds., A Sociolinguistic Profile of Urban Centers in Cameroon, Crossroads Press, Los Angeles, 79-92.

[7] Alobwede, C. (1998) Banning Pidgin English in Cameroon. English Today, 14, 55-60.

[8] Kouega, J.P. (2001) Pidgin Facing Death in Cameroon. Terralingua-Langscape, 21, 11-22. http://www.terralinguaubuntu.org/Langscape/langscape-archive

[9] Mbufong, P. (2001) Pidgin English in Anglophone Cameroon. English Today, 17, 52-53.

[10] Schröder, A. (2003) Status, Functions and Prospects of Pidgin English. Gunter Narr Verlag, Tübingen.

[11] Simo Bobda, A. and Wolf, H.G. (2003) Pidgin English in Cameroon in the New Millennium. In: Lucko, P., Peter, L. and Wolf, H.G., Eds., Studies in African Varieties of English, Peter Lang, Frankfurt, 101-117.

[12] Ayafor, M. (2006) Kamtok (Pidgin) Is Gaining Ground in Cameroon. In: Chia, E., Ed., African Lingistics and the Development of African Communities, CODESRIA, Senegal, 191-199.

[13] Echu, G. (2007) The Politics about Cameroon Pidgin English. Annals of the Faculty of Arts, Letters and Social Sciences, 1, 133-150.

[14] Ngefac, A. (2014) The Evolutionary Trajectory of Cameroonian Creole and Its Varying Sociolinguistic Statuses. In: Buscfeld, S., Hoffmann, T., Huber, M. and Kautzsch, A., Eds., The Evolution of Englishes, John Benjamins, Amsterdam, 434-447. 
[15] Todd, L. (1984) Modern Englishes: Pidgins and Creoles. Blackwell, Oxford.

[16] Ngefac, A. (2016) Sociolinguistic and Structural Aspects of Cameroon Creole English. Cambridge Scholars Publishing, Cambridge.

[17] Nkemngong Nkengasong, J. (2016) A Grammar of Cameroonian Pidgin. Cambridge Scholars Publishing, Cambridge.

[18] Ozon, G., Ayafor, M., Green, M. and Fitzgerald, S. (2017) The Spoken Corpus of Cameroon Pidgin English. World Englishes, 36, 428-447. https://doi.org/10.1111/weng.12280

[19] Kouega, J.P. (2015) A Dictionary of Cameroon Pidgin English Usage: Pronunciation, Grammar and Vocabulary. Lincom Europa, Muenchen.

[20] Kouega, J.P. (2008a) A Dictionary of Cameroon Pidgin English Usage: Pronunciation, Grammar and Vocabulary. Lincom Europa, Muenchen.

[21] Kouega, J.P. (2008b) Market Transactions in Cameroon Pidgin English (CPE). Annals of the Faculty of Arts, Letters and Social Sciences, 1, 113-136.

[22] Kouega, J.P. (2009) Telephone Openings and Goodbyes in Cameroon Pidgin English (CPE). Annals of the Faculty of Arts, Letters and Social Sciences, 1, 45-60.

[23] Nkwain, J. (2011) Aspects of Politeness Strategies in Cameroon Pidgin English. Unpublished PhD Thesis, University of Yaounde I, Yaounde.

[24] Ayafor, M. (1996) An Orthography for Kamtok. English Today, 12, 53-57. https://doi.org/10.1017/S0266078400009317

[25] Ayafor, M. (2014) Cameroon Pidgin English Orthography. 14th International Colloquium of Creole Studies, Aix-en-Province, 29-31 October 2014.

[26] Abu-Humei, A.M.A. (2013) The Effect of Gender and Status on the Apology Strategy Used by American Native Speakers of English and Iraqi EFL University Students. Research on Humanities and Social Sciences, 3, 145-173.

[27] Alsulayyi, M.N. (2016) Apology Strategies Employed by Saudi EFL Teachers. Advances in Language and Literary Studies, 7, 70-83.

[28] Batanieh, R.F. and Bataineh, R.F. (2006) American University Students' Apology Strategies: An Intercultural Analysis of the Effect of Gender, Yarmouk University. Journal of Intercultural Communication, 9, 1404-1634.

[29] Cohen, A.D. and Olshtain, E. (1985) Comparing Apologies across Languages. In: Jankowsky, K.R., Ed., Scientific and Humanistic Dimensions of Language, John Benjamins Publishing Company, Amsterdam, 175-183.

https://doi.org/10.1075/z.22.28coh

[30] Blum-Kulka, S. and Olshtain, E. (1984) Requests and Apologies: A Cross-Cultural Study of Speech Act Realization Patterns (CCSARP). Applied Linguistics, 5, 196-213. https://doi.org/10.1093/applin/5.3.196

[31] Cohen, A.D. and Olshtain, E. (1981) Developing a Measure of Socio-Cultural Competence: The Case of Apology. Language Learning, 31, 113-134. https://doi.org/10.1111/j.1467-1770.1981.tb01375.x

[32] Alsulayyi, M.N. (2017) A Contrastive Study of the Use of Apology Strategies by Saudi EFL Teachers and British Native Speakers of English: A Pragmatic Approach. International Journal of English Linguistics, 7, 45-57.

[33] Brown, P. and Levinson, B. (1987) Politeness: Some Universals in Language Usage. Cambridge University Press, London.

[34] Kouega, J.P. (2007) The Language Situation in Cameroon. Current Issues in Language Planning (CILP), 1-94. https://doi.org/10.2167/cilp110.0 
[35] Lewis, M.P., Simons, G.F. and Fennig, C.D. (2014) Ethnologue: Languages of the World. 17th Edition, SIL International, Dallas. http://www.ethnologue.com

\section{Appendix}

\section{Questionnaire/Interview}

I would be grateful if you could spare a few minutes to answer a few questions for me. These questions are on Pidgin English in Cameroon.

1) Do you think that you speak Pidgin English well?

2) Do you speak and write English?

3) Do you speak a Cameroonian language?

4) Name any three things that someone can do to you that require that he/she should apologise.

5) Can you recall a situation when a friend came to apologise to you for something he/she had done or a situation where you met a friend to apologise for something you have done to him/her?

6a) Can you write the conversation as it happened that day! Write down what he/she said and what you said from the time you met to the time you separated.

6b) Can you dictate to me the conversation as it happened that day! Say exactly what the person said and what you said from the time you met to the time you separated.

7a) Now, let me read to you what you wrote. If there is a mistake, then we will correct it.

7b) Now, let me read to you what you said. If there is a mistake, then we will correct it. 